J O U R N A O F

French and Francophone Philosophy
REV VUE DE LA

philosophie française et de langue française

\title{
'a fine risk to be run': Améry and Levinas on Aging, Responsibility, and Risk in the Wake of Atrocity
}

Jill Stauffer

Journal of French and Francophone Philosophy - Revue de la philosophie française et de langue française, Vol XXIV, No 3 (2016) 38-55.

\author{
Vol XXIV, No 3 (2016) \\ ISSN 1936-6280 (print) \\ ISSN 2155-1162 (online) \\ DOI $10.5195 /$ jffp. 2016.786 \\ www.jffp.org
}

\section{(c) EY-NC-ND}

This work is licensed under a Creative Commons Attribution-Noncommercial-No Derivative Works 3.0 United States License.

\section{ULIS D-Sunt}

This journal is operated by the University Library System of the University of Pittsburgh as part of its D-Scribe Digital Publishing Program, and is co-sponsored by the University of Pittsburgh Press 


\title{
'a fine risk to be run'
}

\section{Améry and Levinas on Aging, Responsibility, and Risk in the Wake of Atrocity}

\author{
Jill Stauffer \\ Haverford College
}

Does atrocity age? What I mean to ask is, does time heal wounds that were genocidal or otherwise broad, deep, and caused by a fatal combination of human depravity and widespread indifference? Jean Améry famously refused to let the past be past in his essay "Resentments." He argued that even if, with regard to the Holocaust, logically speaking, what happened is in the past, there is no moral sense to that. Morality requires of us that we refuse to let the past be whenever we are faced with a past that should have been otherwise. For him, writing 20 years after he was freed from the camps, time had not healed all wounds. Atrocity was not aging gracefully.

But what does it mean to ask if atrocity ages? Trees and other plants, animals and ecosystems, they have lifecycles, are born, grow, and die. So do human beings. Memory changes or fades. Time passes. Human beings age, whether they want to or not. For human beings, aging is both undergone passively and engaged actively. I don't become an adult only due to an accumulation of years. Maturity is an achievement wrought both in my participation and by the influences others have on me, for better and for worse. As the years pass, I learn, make mistakes, undergo discipline, embrace liberty; I live and work alongside others, sometimes joyfully, other times grudgingly; I take advice or ignore it; I reside in the flow of a community or perhaps struggle against its norms; and all of these things contribute to making me who I am. I didn't get to choose them all, and yet these things, and the time it takes for them to be, are the living, embodied archive of what time has been for me.

We humans sometimes, unreflectively, think of time only as a steady passing of minutes and years, something measured and measureable, that we can record and, to a certain extent, predict. Améry points out that because we know that time heals a minor injury like a cut or a bruise, we predict that its passing will also heal larger and more complex harms, like 
the loss of a loved one or the trauma of torture. He calls this the "natural time sense," and he writes about it in relation to both recovery from moral harm and human aging. Emmanuel Levinas also writes about aging as it relates to loss and moral responsibility, though the style, aim and outcome of his thinking differs from Améry's in key ways. Read productively alongside Améry's meditations on aging and loss, Levinas' philosophy may help to put aright the "total inversion of the social world" imposed on Améry by torture and dehumanization."1 This essay will look the passing of time, for Améry and for Levinas, to see how a dialogue between them may open up possibilities for thought about time, aging, loss and recovery.

\section{Overcoming negative knowledge}

"Atrocity" stands, as a term, for a collection of cruel actions imposed by some human beings on other human beings. That the human world is full of such acts is part of what gives the past its weight, and makes it hang more heavily on some than others. That points us toward a knot in time's flow. Human beings who have imposed or undergone grave harm, especially those who have undergone it, may have a hard time believing about the past that it is past, if 'past' also means over and gone. Traumas resurface, resentments remain, and trust in the world, once broken, is difficult to rebuild. That is why Améry insists that time does not heal harms on its own. Human beings may work to heal wounds, or fail to do so, or they may try to heal themselves or others and then find that it is easier said than done, with some kinds of injury.

Of course the passing of time may make some things easier to live with-perhaps especially for those who would like to forget because they can. But you don't have to survive atrocity to know that the past does not always stay in the past. We're all haunted by what could have been and what should never have happened.

That we all reside, in some measure, with legacies of grave harm is why Améry insists that, in some instances, we have a moral duty to refuse to let the past be past. If unjust treatment of some human beings by other human beings isn't marked for what it is but instead is allowed to slip into a past as-is, harms and culpabilities unacknowledged, injustice persists. And then injustice expands. It expands because now it's no longer only the injustice of what happened but also the injustice of refusing to deal adequately with what happened - insult added to injury, or even a second injury. As I argue in my book Ethical Loneliness: The Injustice of Not Being Heard, that second injury makes recovering a sense of the self's place in the world difficult for those whose safety was destroyed by atrocity.

Améry was discriminated against because he had one Jewish parent; he escaped from his homeland, Austria; he was apprehended as part of the 
Belgian resistance movement; he was tortured, beaten, starved and dehumanized in concentration camps, left to live in impossible conditions for many years; and that experience stayed with him not only in terms of the marks of torture or the physical problems created by long-term ill-treatment. It also taught him that the neighbor who smiles in the street today might report you tomorrow, look the other way when you are hauled off by thugs, or believe too easily that if so many people hate Jews so much, they must deserve it. Améry has a specialized form of negative knowledge about human possibility. He writes movingly about how torture destroyed his trust in the world. But he also makes clear that it isn't only torturers who caused and continue to cause him pain. His torture was only possible against a backdrop of such widespread cruelty and indifference that Améry had to believe, for practical reasons, in the collective guilt of Germans: "Collective guilt. That is naturally sheer nonsense if it implies that the community of Germans possessed a common consciousness, a common will, a common initiative to act, and therein became culpable. But it is a useful hypothesis if nothing else is meant by it than the objectively manifested sum of individual guilty conduct." 2 Otherwise put, if Améry had to be equally afraid of a black-booted SS officer as he was of an innkeeper, a secretary, or anyone else he encountered, because only the combination of active willed evil, widespread racist collaboration with that evil, and massive indifference to the fate of those caught in its violent web make mass murder possible, then collective guilt makes sense as a term, defined as he defines it: "I, too, had to determine the quantity of good comrades on the one hand and of the scoundrels and indifferent ones on the other when, in the midst of the German people, I had to reckon every moment with falling victim to ritual mass murder." 3 This - the knowledge that not just evil men but ordinary human beings you meet on the street every day will allow genocide to occur - is what Améry wants the world to undo for him. How does a human being recover when trust in the world has been replaced by deep knowledge of humanity's potential indifference to any harm that might befall you?

Daydreaming about the possibility of Germany repudiating everything it produced between 1933 and 1945, Améry remarks that this negation of a negation would be a "highly positive, redeeming act. Only through it would our resentment be subjectively pacified and have become objectively unnecessary." 4 It may seem like an impossible demandobliterating everything good and bad that could be made in Germany during the years of Nazism. But the request gives us a sense of both the weight of the past and the depth of its hauntings. What could sound like an impractical or intransigent refusal to let the past be past is made for the sake of exploring what would make it possible to let it go. That is, Améry's essay, if read well, shows us one way atrocity might age well instead of badly. He suggests that: 
the problem could be settled by permitting resentment to remain alive in the one camp and aroused by it, self-mistrust in the other. Goaded solely by the spurs of [survivor] resentment... the German people would remain sensitive to the fact that they cannot allow a piece of their national history to be neutralized by time, but must integrate it. 5

Time's passing doesn't cause recovery or reconciliation if injustice is left unaddressed, if structural harms are not repaired, or if deep-seated attitudes do not change. This will be true everywhere but Améry's example is Germany. And so he insists that what happened in WWII must be made part of the story Germany tells of its history.

\section{Améry's problem}

Reading Améry's arguments in "Resentments" and the other essays in At the Mind's Limits can be sobering, inspiring and frustrating. His position on time and resentment is logically sound, makes an important ethical demand on its readers, and its obdurate character is understandable, given his history. The power of his unflinching account of what he lost and how he lost it has much to teach us about harm and recovery. He tells us what needs to be done: the world must be rebuilt to allow him to regain trust that his humanity will be respected and he'll be offered help when it is needed. He does not tell us how to do that-unless you think it really might come to pass that Germany would repudiate and destroy everything it produced between 1933 and 1945, or that that would get the job done if it did happen. Améry may not tell us how to fix the world because he thinks that should not have to be his job. (He's probably right.) But I also think the 'how' of fixing the world is not possible within the terms of his argument. What I mean is, achieving what Améry asks for requires something more than the persuasive power of logic or a solid description of the problem (two things he offers us). After all, he is basically asking the whole world to think differently about what human beings are responsible for and how they come to be responsible. But he is also disappointed, always already predicting defeat, fairly sure he won't succeed in being heard on his own terms. In "On the Necessity and Impossibility of Being a Jew" he writes, "I was unable to force yesterday's murderers and tomorrow's potential aggressors to recognize the moral truth of their crimes, because the world, in its totality, did not help me to do it." 6 He's not wrong. In the 1960s he was writing against a tide of willed recovery that had not fully dealt with what the past had wrought. He continues:

Where there is a common bond between me and the world, whose still unrevoked death sentence I acknowledge as a social reality, it dissolves in polemics. You don't want to listen? Listen anyhow. You don't want to know where your indifference can again lead 
you and me at any time? I'll tell you. What happened is of no concern of yours because you didn't know, or were too young, or not even born yet? You should have seen, and your youth gives you no special privilege, and break with your father. ${ }^{7}$

Here he imagines various possible responses to his argument. He describes common attitudes and then addresses them as if converting those attitudes is not his job. (Again, it shouldn't have to be his job.) But without such conversion, I'm not sure the change he demands is possible. He could not feel safe because the world did not help him feel that way. But what would make people living in that world help? His response: "Listen," "I'll tell you" what you don't want to hear, and "break with your father." These aren't unreasonable demands to make on an audience. But I'm asking what makes it possible for someone both to hear these demands and feel called to respond with help rather than sinking back into the attitude that time will get the job done on its own.

\section{Levinas' solution}

Levinas' personal history is also marked by loss from the Holocaust. Because he was in the French army, he survived in a prisoner of war camp rather than being sent to the death camps. His wife and daughter also managed to stay alive, in hiding. No one in else in his or his wife's families survived. And yet his way of philosophizing in the wake of that loss differs from Améry's. I'm going to avoid the temptation to psychologize on their behalf, to draw conclusions based on what is different between being tortured and being badly treated in as a prisoner of war, and so on. I'll focus instead on what they argued when they set out to use philosophy to make ethical demands on their readers.

As we've seen, Améry's reaction to total world destruction is to hunker down, require recognition of what happened to him and to so many others, and demand a world where he could reasonably feel safe from repetition of the deep and varied harms he underwent. If the Levinas of Totality and Infinity also shores up safety - by building a world out of family relationships and a future out of child-bearing (admittedly, this is a tremendous reduction of what that book sets out to do) - the later Levinas, of Otherwise than Being, foregoes that security, breaking up stable foundations of identity to which we might wish to cling, and does so in the name of an ethics that would not and could not leave any human beings to their deaths. Levinas chooses a riskier path, but one more capable of bringing about the transformation Améry so desired.

He does this by building a vigilance with regard to other human beings into his theory of subjectivity, housing responsibility for others so deeply within self-formation that the only way to escape it is "in the scruple 
or remorse which precedes or follows this refusal." 8 Any of us may, in the light of reason, give ourselves reasons why we don't owe something to others who need our responsiveness. Some of the reasons may be justified or logical, others simply convenient or wishful, but all of them will be what Levinas calls "scruple or remorse," ways of explaining to ourselves after the fact of feeling the call of responsibility why we don't owe what we also do owe. Law may say you don't bear a responsibility that some other standard-decency, morality, ethics, community, and so on-says you do. Being faced with suffering that you didn't directly cause may make you wish you didn't have to think about it. Or it might make you wish, fervently even, that you could do something to help. You may feel shatteredconsciously or unconsciously - that you are powerless to do something or do more. And it may thus be a relief to have reasons not to help - say, you don't give money to homeless people on the street because they'll spend it on drugs or because they don't speak to you politely or because those problems are better handled by qualified organizations or you just can't deal with thinking about your complicity in their fate, and so on. But the scruple (reasons offered) and the remorse (feeling bad despite the reasons) are signs of a prior call.

Levinas builds this "prior call" into self-formation by showing that we both are and are not discrete individuals. On the one hand, I am who I am and no one else is that self - I know that when I feel isolated by the limits of what can be communicated about my self and its conditions, and when I observe those limits between myself and others. On the other hand, I'm not just a monad locked up in itself. I'm also a body vulnerable to sense and contact. There are others out there; I sense them, and they have an impact on me, positive or negative, long before I have the time to decide whether or not to be affected. That exposure is part of my self-formation.

Because of that exposure, for Levinas the self is made up of multiple parts or influences. There is a part of the self that considers itself sovereign, sinks down into its enjoyment of its own embodiment and the surrounding elements, savoring food and drink and other pleasures. It is concerned only with itself. But the means of that self-concern-sensibility - is also the way in for outside influences. That same self will sense others out there, wanting response, possibly needing help. The part of the self affected by others will inevitably bump up against the part that only wants to enjoy being for-itself. And those two movements or moments of self-sovereign and affectedhappen simultaneously and constantly as waves of affectivity and sensing. That is what a self is. It means that I am, deep within myself, a selfsame thing always already affected by what is outside of myself, so much so that the boundaries between inside and outside are not distinct. At a core level of the self, I am not able to remain at home with myself, locked away from what affects me. ${ }^{9}$ 
I've said this path is riskier than the one Améry took. How is that so? Améry, understandably, wants the world to give him back the certainty he once had that he belonged to humanity and deserved fair treatment. ${ }^{10}$ Levinas wants to remove that certainty equally from everyone to make a point about what makes it possible. He asks us to look for traces of experiences that happen in a non-time that cannot be recovered, to find signs of those undergoings in our own vulnerability, in aging, in the weariness with which we sometimes approach our own life-as if refusal to take up one's own life could succeed-and then to read, after the fact, the significance of those signs as capable of teaching us something about how we are formed and thus, what we owe to others. To say the least, this could fail. As I've shown and will elaborate, there are so many other reasons, most of them of the sort we are well-trained to recognize as more legitimate than feelings and senses marked after-the fact, that we might offer to talk ourselves out of knowing what we know about our response to others and what that response can tell us about a duty to respond. That is why Levinas admits that

communicating with the other can be transcendent only as a dangerous life, a fine risk to be run. These words take on their strong sense when, instead of only designating the lack of certainty, they express the gratuity of sacrifice. In a fine risk to be run, the word 'fine' [beau] has not been thought about enough. It is as antithetical to certainty, and indeed to consciousness, that these terms take on their positive meaning [leur sens positif]...11

The work of reason leads us to call what we 'know' prior to reason 'uncertain.' But we are capable of reading the signs that show how incomplete the term 'uncertainty' is here. We can't choose against the sense of being affected by others, but what we do with that sense is not guaranteed. We might build a world where others are safe. We might protect ourselves and leave others out of our thoughts. We might harm others and make excuses for why it is necessary. These are all human possibilities. But the uncertainty behind these rationally formulated certainties ought to weigh on us, make us think carefully about choices we have made and will make. If we have not lived up to the call of responsibility, it does not remove from us the responsibility we have to make the world safe for others and ourselves, no matter how many excuses we give. Still, we might fail to be responsible. It is a risk to think ethics in this way, and this risk takes on its "positive meaning" when we consider the sacrifices we may be called to make in order to be just to others as well as what may happen to others and ourselves if we do not live up to our responsibilities. 


\section{Resistance}

Does any of this help us think about what troubled Améry? In his essay on torture, Améry writes, "torture becomes the total inversion of the social world, in which we can live only if we grant our fellow man life, ease his suffering, bridle the desire of our ego to expand. But in the world of torture man exists only by ruining the other person who stands before him."12 Améry describes torture as a destruction of self. When a human-caused harm is inflicted "against which there can be no defense and which no helping hand will ward off, a part of our life ends and it can never again be revived."13 Why? Because, for Améry, what destroyed him was not only loss of sovereignty-power over his own embodiment and choices-but knowledge that no one would help him. So if (as I argue in Chapter 1 of Ethical Loneliness), for Améry, dehumanizing treatment was defined in part by the loss of any expectation of help, then part of what makes humanity human is the expectation that just treatment or help is owed. What Améry needs is a way to fix a world that has been inverted by cruelty.

As we've seen, Améry took this important insight and used it to back an unbending moral claim for recognition of past harm and broad responsibility for restitution. He demanded a world where he could trust that others would respect his humanity and offer help when needed. It is a reasonable demand. Levinas builds response to that demand into a theory of subjectivity; he gives us one way to de-invert or put aright the "total inversion of the social world" described by Améry.

Would Améry accept Levinas' solution? Perhaps we can't know the answer to that question. But I would guess that he would find it difficult, for many reasons, but perhaps foremost because the camps stole from him the capacity to believe in things that "transcend reality." He describes how, in the conditions of the camps, "to reach out beyond concrete reality with words became before our very eyes a game that was not only worthless and an impermissible luxury but also mocking and evil. Hourly the physical world delivered proof that its insufferableness could be coped with only through means inherent in that world."14 In that statement he is explaining how philosophy and literature lost the power to give his life meaning when living was reduced to trying not to die in a situation of severe deprivation. He lost the transcendence wrought by thinking and aesthetics and, since he was neither religious nor particularly caught up in Marxist ideology (two forms of transcendent succor he witnessed at work in fellow camp dwellers), he lost transcendence as a route out of his present situation. He may have gotten back some of his pleasure in texts in the years following the war, and in fact he made a living as a writer and thinker. But I think the initial loss of transcendence as a possibility stayed with him. One might even recognize the work of At the Mind's Limits as a description of the life of someone who has given up hope of transcendence but desperately needs a way out. As we've seen, his strategy was to demand that others build a world where he 
could trust he would be safe. What Levinas gives us, I've argued, are the background conditions where that might be possible.

\section{Améry aging}

Améry no longer believes in transcendence-if he ever did-and so he wants a restored past instead. But he's aging. And that, for him, is the site of a complication. Discussing his life as an Austrian exiled post-war in Belgium, he admits he has no desire to return to Austria because the events of the war showed him that he had lost a country that had never been his in the first place. Because he was Jewish (by blood if not tradition), he had never belonged, even when he felt that he had. The events of the war taught him that indelibly. But he also points out that even those who wish to and are able to return do not enact a full return, "because the re-entrance into a place is never also a recovery of the lost time."15 Permanent exiles such as himself are faced with a life lacking the kind of history that makes "home" possible. Customs, phrases, the way persons hold their faces, engage in pleasantries, pronounce vowels or consonants, everything is different. There is no longer any zone where one might feel fully secure, "where no chance occurrence is to be expected, nothing completely strange to be feared.16" Anyone who has transplanted herself from one place to a new and different place will know the truth of this. Every day means walking through unfamiliar streets looking for a bank, a grocery store, a friendly face, and possibly finding none of them. It's like being kicked out of a way of being - a form of homelessness. "Penetrating the signs will not be a spontaneous but rather an intellectual act, one combined with a certain expenditure of mental effort. ${ }^{17 "}$ Améry had to trade, against his will, the world in which he had been raised and in which he had developed his sense of home for a foreign location. He writes that "we are accustomed to living with things that tell us stories. We need a house of which we know who lived in it before us, a piece of furniture in whose small irregularities we recognize the craftsman who worked on it. We need a city whose features stir at least faint memories of the old copperplate engraving in the museum."18 Each of us needs the security of a dwelling place that feels like home. Not everyone needs as much or precisely the things Améry described. After all, there can also be joy in the new. And the passing of time makes changes even in "the same" for those who don't move. So there is some nostalgia in Améry's longing, a belief that he would be at home, or even that not much would have changed, had war and racism not evicted him from one life into another. But his experience of dislocation, of being foreign and having no homeland to return to, is real.

He learns this, he says, in the experience of aging: "aging makes us dependent to an increasing degree on the memory of the past."19 For Améry, a young person is not only who he is but who he will be; an old person is 
only who he was. But what 'was' Améry if, looking at his history in Austria, he cannot detect himself anywhere in it? Of that region's various exiles he says, "their past as a social phenomenon had been retracted by society," no matter how successful or settled they had been therein, "thus it was impossible to still retain it as a subjective, psychological possession." 20 This is the loss, for Améry, not only of a past, but of the possibility of home. He ties this neatly to his observations about the harms of dehumanization when he writes, "the past of the neoromantic poet Alfred Mombert... flowed from the world on the day when a seventy-year-old man by the name of Alfred Israel Mombert was deported from Karlsruhe and no hand was lifted to protect him."21 Again, it isn't only the harm visited but the loss of the capacity to expect help from others when in danger that destroys lives and worlds. In aging, Améry finds more in this loss: Mombert's "readers of yesterday, who did not protest against his deportation, had undone his verses." 22 If you remove someone's humanity, as the cruelty and indifference of racism and genocide do, you also strip them of a past built on a false trust that the world would grant them shelter. And if aging means that all you have is the past, then in aging after dislocation you have nothing. As Améry writes, of those who have reached old age: "for those who have nothing or just a little or only something inessential to expect, who climb down into the past with its deep well, they stay quietly in their place." 23

Levinas writes, of the other human being, for whom I am responsible: "He has no other place, is not autochthonous, is uprooted, without a country, not an inhabitant, exposed to the cold and the heat of the seasons. To be reduced to having recourse to me is the homelessness or strangeness of the neighbor. It is incumbent on me." 24 Whether or not Levinas and Améry ever read each other's work, we can read this as a response to the loss Améry describes. Levinas is not talking about refugees or exiles as a political category but rather as a sign describing, elliptically, human vulnerability and human response. At the level of our formation as subjects and our vulnerability to harm we are all homeless. And we all owe shelter to those who need shelter. Levinas writes, "the ego is in itself like a sound that would resound in its own echo, the node of a wave which is not once again consciousness." 25 The preconscious level at which this demand originates is the source of its risk but also its strength. The ego is the part of the self that thinks itself sovereign, but that self resounds, sends and receives waves, and is affected by those prior to any conscious choice to be so. Because of this, the self is in itself "as an exile": being affected prior to choice means one is never simply at home with one's sovereign self; one is always already interrupted by the sense that there are others. Levinas adds that the subject "will be found under the effect of an expulsion, whose positive meaning has to be explicated.... There is expulsion in that it assigns me without recourse, without fatherland, already sent back to myself, but without being able to stay there, compelled before commencing." 26 Every return to the self is also 
an expulsion, when the self finds the needs of others deep within itself, affectively undergone, and responds despite itself.

I've already discussed the various ways we find to refuse this call of responsibility. But it is against the background of this call that we build worlds where homes are possible. It is only when we neglect to do that that homes are not possible. It may be preconscious that the self is "without a dwelling place, expelled from everywhere and from itself, one saying to the other 'I' or 'here I am,'" where "I" means here I am, for the others, but it is possible to dwell in that response consciously too, to allow oneself to be reminded of it - as the experience of aging does for Levinas, as we'll see. ${ }^{27}$ Earlier we guessed that Améry might have a hard time accepting what Levinas argues because Améry did not believe in transcendence. He wrote of life in the camps that "hourly the physical world delivered proof that its insufferableness could be coped with only through means inherent in that world." 28 But it should be clear by now that Levinas' form of transcendence also relies on means inherent in the world in which we live. We undergo a call from the other provoked in us by the very presence of others and undergone by us bodily in waves of affectivity and sensibility. This is the body's archive recording a responsibility no one had time to choose. So what Levinas offers responds, at the level of background conditions of possibility, to what Améry has lost. I may be stuck in myself but that is not a simple sovereign isolation of the self: "only the meaning of the other is irrecusable, and forbids the reclusion and reentry into the shell of the self. A voice comes from the other shore. A voice interrupts the saying of the already said." 29

\section{Améry and time}

For Améry, time is both an intimate friend and an arch-enemy, and really can only be known by those who have entered old age. For young people, when we say that they have time stretched out in front of them, what we mean is that they will build worlds and expand in space. Time is not their concern; indeed, young people don't tend to think much about time. It does not weigh on them as it does on those who have stored up the passing of many years. According to Améry, time matters to older people mostly because there is less of it, less time for world-building, and so what looms large, rather than world-building or the future, is the past, which increasingly stays in the present rather than remaining in the past. Aging isn't so much awareness of one's wrinkled visage or bodily pains (though those things are part of why "time lies heavily within" older persons) but "how little world I still have before me!" 30 He continues: "Those who believe they have what is called 'time' in front of them, know that they are truly destined to step out into space, to externalize themselves. Those who have life within them, i.e., authentic time, have to be internally satisfied with the deceptive magic of memory." 31 What Améry calls "authentic time" here 
means the body's archive of years, the closing down of possibilities, and the sense that one is running out of time. "The real has washed over what was once possible." 32

Loneliness attends these decreased possibilities as, for Améry, to be in time rather than space is also to be alone rather than together with others: "space, even my space, the possession of which gets me through the spatial form of intuition, is likewise always the space of others: an intersubjectively understandable phenomenon." 33 If one has trouble describing any phenomenon in space (the color 'blue,' for instance), one can point at it in the shared world to communicate about it. ${ }^{34}$ But Améry does not think it is possible to make one's feeling for time accessible to others: "But with my time I am alone, no matter how much I may be required to communicate it. 35 " He believes time is purely an inner sense, unlike space, which is external.

Of course, there are externalized forms of time. Améry writes: "Existence within society forces us to own a watch, to write down appointments in a notebook, to reserve a place on the ferry for a trip on a particular day across the English Channel." 36 We know this, and it is how we function on a daily basis. It is useful, but it also keeps us from considering time more deeply. As Améry adds, "In the peace that comes with freedom from thinking, we have a past, present and future, as they are expected of us because we are meant to be functional. But in the end, what's not questionable to us, precisely that 'natural feeling for time' ... may still be different from comfort and acquiescence to the law of the functional." 37 The natural feeling for time, a concept he developed first in At the Mind's Limits, happens when we note that physical wounds do heal and then extrapolate outward to say that time heals all wounds. Of course that's true at least part of the time, and perhaps it truly is the "natural feeling for time." (In a longer essay I'd say more about whether this argument works as well in discussing aging as it does in discussing a moral duty to redress past harm.) But accepting the "natural feeling for time," though it goes beyond taking time merely as an externally imposed function, also neglects to think deeply about time. Améry asserts that "to meditate about time is not natural and is not intended to be so," and uses that to remind us that the healing of wounds can be deceptive and aging is more than a biological fact. ${ }^{38}$

\section{Levinas, aging otherwise}

Can we pull positive meaning out of the idea that the body is an archive of time's passing or, as Améry puts it, "an aging human being is a bundle of time or a stratified mass of time" ${ }^{39}$ This must mean different things at different ages. Améry is likely right that someone who is 20 or 30 probably doesn't think of their body as an archive. At the age of 50 I can tell you that I do, and there is as much good about that as there is bad. Another truth 
about aging is that people who haven't reached a particular age probably do not know what they are talking about when they philosophize about it. In the preface to the $4^{\text {th }}$ edition of On Aging Améry mentions a critic of an earlier edition who asked: "what could this 'young' person of 55 years, J.A., understand about aging and age?" 40 Point taken. But it is not only numerical age that makes these differences. What 20 or 60 is for one person is not what it is for another, for various reasons.

For Levinas, aging is "an obedience where there is no desertion," a passive synthesis in the body of the passing of time, something more than what the identification of the ego with itself could reckon on. That sounds, on first listen, as depressing as Améry's take on things. But for Levinas it is evidence of a lapse of time that is not recuperated, a beyond to the stories we tell ourselves about what we will in the freedom of our wills. ${ }^{41}$ This is significant, for Levinas, because aging, if we attend to it, teaches us about our deep responsibility by showing us temporality in multiple registers. Anyone who has aged beyond youth knows that aging shows the passage of linear time. Aches and wrinkles and maladies of aging that were not there before appear and time does not go backwards to remove them. Améry says as much. Time advances in one direction, and that is one way in which aging is "an obedience where there is no desertion." But aging is more than that, which is why Levinas repeats that phrase and then qualifies it: "Subjectivity in aging is unique, irreplaceable, me and not another; it is despite itself in an obedience where there is no desertion, but where revolt is brewing. These traits exclude one another but they are resolved in responsibility for another, older than any commitment." 42 What does Levinas mean here?

In aging time passes (le temps se passe), but this passing isn't present in consciousness. One does not feel oneself aging, usually. In consciousness aging arrives after the fact. We look in the mirror or at old photographs or we undertake a strenuous hike and note, perhaps with surprise, the passage of time that our body has already undergone. Levinas' point is that there is a form of aging or decay that is removed from memory, but which has occurred-in an irrecuperable temporality. For Levinas, that lapse is a diachrony, a time marked by "a disjunction of identity where the same does not rejoin the same." 43 In other words, it is evidence of the subject's lack of total possession of itself. It "confirms" Levinas' description of the subject as always partially evicted from its own self. It also finds a place for what memory and history might fail to record. Not everything that makes me what I am comes from what I willed; aging is one powerful piece of evidence in support of that truth. Aging may also teach us (if we listen) that we are not only the selves we will ourselves to be. This points toward a (non-) space or time when we become ourselves only by answering a prior call from others who are not us. That is the obedience, but where is the revolt? Pre-conscious responsibility means I cannot "stay at home" with myself. That I always answer the call-the call that ties me to my 
responsibility but makes it impossible to remain alone inside my selfmeans that revolt occurs on multiple levels. There is the part of me that wants to be concerned only with itself, doing its best to sink down into its own self's enjoyment-revolt against the call of the other. And there is the part of me that senses a responsibility owed to others, feels it as infinite, knows that infinity is not possible for a finite being, and yet crosses over that difficulty and takes responsibility anyway - revolt against my own finitude. I do what I can, which may also be more than I thought possible. In a site where Améry finds inescapable solitude and loss of the past, Levinas describes inescapable intersubjectivity and response to others. Here is how Levinas frames it:

[the subject] is someone who, in the absence of anyone, is called upon to be someone, and cannot slip away from this call. The subject is inseparable from this appeal or this election, which cannot be declined. It is in the form of the being of this entity, the diachronic temporality of aging, that there is produced despite myself the response to an appeal, direct and like a traumatizing blow. Such a response cannot be converted into an 'inward need' or a natural tendency. 44

In being a self I have already responded to others. If I doubt something that important could happen and I wouldn't remember it, along comes aging to confirm that sometimes what memory doesn't contain has actually occurred. Time passes in aging, but we capture it only later; there is a form of time that we do not recover. It might hit like a "traumatizing blow." But within that missed time we have already heard and responded to the call of others; that is what has made us unique subjects. After the fact we might explain all of this - the aging, the sense that we owe something to others - in various ways, and many of them may be rational and backed by evidence. Social contracts, social science studies of human motivation, natural science studies of life processes, political or community processes of consensus, systems of rules, state power or local agreement, domination whether overt or hidden-these and many other human inventions describe what human beings are, how they got that way and what is possible for them. They even give us evidence with which we might mount a counterargument to what Levinas says about time, responsibility and aging. I might say: I'm not responsible because of some unchosen call; rather, I'm responsible because a rational actor behind a veil of ignorance would have chosen this, or; I respond because empathy is culturally learned or an evolutionary adaptation, or; I respond because that is the norm of my community, or that is what the rules require of me, or that will secure the best overall outcome for everyone; and so on. Levinas' point is not that those things aren't true but that they come late. Aging, as passivity before time, is nothing we can choose against. But it is also an opportunity, a space or time where we might notice the limits to what all human inventions can explain or achieve. Those 
limits may point out for us, if we look, responsibilities that, considered carefully, explain other things.

That leads us back to Améry's text, where he tells us what needs fixing but not how to fix it. My reading (done more thoroughly in Chapters 1 and 4 of Ethical Loneliness) is that Améry needs the perpetrators of his losses (including those who stood by and let it happen as much as those who actively caused the harm) to admit what they did was wrong, own it as a failure, and build a world where the great majority of people agree that what happened should never have happened and will not be allowed to happen again. That is an utterly reasonable demand. But what, beneath the rationality of his claim's logic, is he asking for? Seemingly he is asking the world to think differently about responsibility. Those who stood by and did nothing and those who didn't actively kill but facilitated a genocidal regime must take responsibility in a way that transcends concern with Kantian autonomy, legal culpability, or the idea that one can be "responsible" only for acts freely willed and committed. Every genocide has furnished proof that it isn't only murderers who make genocide possible. Such grievous injustice is made possible only when hundreds or thousands or millions of people do nothing about something they know to be wrong. They may do nothing because they feel powerless or because the situation is so complicated that it is not clear what can be done. They may do nothing out of political calculation or depraved indifference or blameworthy ignorance. But what if the great majority of human beings felt, deep within themselves, a form of responsibility for others that made the excuses we make for doing nothing less convincing? That is one aspect of the 'risk' Levinas offers to us.

\section{Taking risks}

Améry couldn't return to a homeland that time and war had shown him had never truly been his. And he says that even those who can and wish to return never fully return "because the re-entrance into a place is never also a recovery of lost time." 45 Levinas shows us that the archive of each of our bodies contains within it evidence of a lapse of time that is not recuperated, and does so in a way that shows us an undeniable responsibility for others rather than resonating only as endless loss. The loss is still there. But it stands not only for bereavement but for a commitment to protect others from loss. Levinas' account of responsibility shows how aging-as something both passively undergone and actively engaged-may help us think about the passing of time in restorative ways, even post-atrocity. When we reflect on the preconscious and intersubjective conditions that make us who we are, and we become the kind of people who create space where that call can be heard, we build worlds where such a call resonates. We build worlds. Améry says that young people don't concern themselves with time but rather build worlds and expand in space. If Améry had 
thought about time and aging differently, he may have been able to see that people of all ages have that power, and that it matters.

In At the Mind's Limits Améry shows us a problem. Levinas' remarks on aging in Otherwise than Being point us toward a way out of the negative knowledge about human possibility that Améry knew so well. We are formed intersubjectively in such a way that it should not be possible for us to justify abandoning any human beings to torture, dehumanization and death, nor find ourselves blameless when we do.

I argued earlier, about what Levinas calls responsibility-for-the-other, that it hangs on each of us whether we like it or not, that we can't choose against it, and yet in the lives we lead it is there to be taken up - and we might fail to do so-and all this is true at once, constantly, in our relations with others. We may catch sight of this if we take the time to reflect on things we don't remember but which have happened-like aging, and being formed intersubjectively prior to choice. We may also be able to describe responsibility in other, more rational ways. And we can explain away the "scruple or remorse" that accompanies refusal of responsibility. But what do we miss when we think that these kinds of explanations and excuses capture the totality of what might matter to and between human beings? Améry did not wish to risk believing in transcendent solutions. Levinas gives us a form of transcendence that keeps us firmly rooted to the earth - but he did know it was a risk to take seriously a responsibility that we both can (rationally) and cannot (at the level of subject formation) refuse. We may understand why Améry couldn't take the risk. But maybe you can take it? And then act on it? That would be one way to give Améry what he wanted.

${ }^{1}$ Améry, Jean. At the Mind's Limits: Contemplations by a Survivor on Auschwitz and its Realities. (ATML) Bloomington, IN: Indiana University Press, 2009, 35.

${ }^{2}$ Améry, ATML 74

${ }^{3}$ Améry, ATML 75

${ }^{4}$ Améry, ATML 79

${ }^{5}$ Améry, ATML 78

${ }^{6}$ Améry, ATML 96

${ }^{7}$ Améry, ATML 96

${ }^{8}$ Emmanuel Levinas, Otherwise than Being or Beyond Essence. (OB) Trans. by Alphonso Lingis. Pittsburgh, PA: Duquesne University Press, 1998, 6-7

9 This paragraph condenses and simplifies Levinas' description of subject formation in the chapter called "Substitution" in Otherwise than Being. 
10 To have certainty that one will be treated well and then lose that is different from never having had that certainty at all-and so Amery's plight is different from that of some others who are subject to atrocity. I discuss this in Ethical Loneliness: The Injustice of Not Being Heard. New York, NY: Columbia UP: 2015, 33, and Chapter 3.

${ }^{11}$ Levinas, OB 120. In French: Emmanuel Levinas, Autrement qu'être ou au-delà de l'essence, Livre de Poche, Paris (orig. Martinus Nijhoff, 1978), 191.

${ }^{12}$ Améry, ATML 35

${ }^{13}$ Améry, ATML 29

${ }^{14}$ Améry, ATML 19

${ }^{15}$ Améry, ATML 42

${ }^{16}$ Améry, ATML 47

${ }^{17}$ Améry, ATML 48

${ }^{18}$ Améry, ATML 57

${ }^{19}$ Améry, ATML 57

${ }^{20}$ Améry, ATML 59

${ }^{21}$ Améry, ATML 60

${ }^{22}$ Améry, ATML 60

${ }^{23}$ Améry, Jean. On Aging: Revolt and Resignation. (OA) tr. by John D. Barlow, Bloomington, IN: Indiana University Press, 1994, 19.

${ }^{24}$ Levinas, OB 91

${ }^{25}$ Levinas, OB 103

26 Levinas, OB 103. Lingis' translation skips over some of Levinas' words. A more thorough translation of the midsection of the quotation might read: “...expulsion in that it assigns me prior to my showing myself or setting myself up; I am assigned without recourse, without fatherland..." See Autrement qu'etre 163.

${ }^{27}$ Levinas, OB 146

${ }^{28}$ Améry, ATML 19

${ }^{29}$ Levinas, OB 183

${ }^{30}$ Améry, OA 15

31 Améry, OA 15

${ }^{32}$ Améry, OA 19

${ }^{33}$ Améry, OA 22

${ }^{34}$ Améry, OA 8

${ }^{35}$ Améry, OA 22

${ }^{36}$ Améry, OA 25 
${ }^{37}$ Améry, OA 25

${ }^{38}$ Améry, OA 26

${ }^{39}$ Améry, OA 20

${ }^{40}$ Améry, OA xviv

${ }^{41}$ Levinas, OB 52

42 Levinas, OB 52

${ }^{43}$ Levinas, OB 52

${ }^{44}$ Levinas, OB 53

45 Améry, OA 42 